Ann. Biol. anim. Bioch. Biophys., 1978, 18 (4), 1001-1005.

\title{
Plasma gonadotropin, estradiol, and vitellogenin and gonad phosvitin levels in relation to the seasonal reproductive cycles of female brown trout
}

\author{
par L. W. CRIM, D. R. IDLER \\ Marine Sciences Research Laboratory, Memorial University of Newfoundland, \\ St. John's, Newfoundland AIC 5S7, Canada.
}

Summary. Profiles for plasma gonadotropin, estradiol, and vitellogenin were obtained in female brown trout during the seasonal reproductive cycle. The accumulation of yolk lipophosphoprotein (phosvitin) in the gonad was also followed. Plasma estradiol and vitellogenin concentrations rose progressively and parallel increases in ovary yolk phosvitin were observed. Gonad development continued while plasma gonadotropin levels remained low and unchanged until oocyte maturation was underway. LH-RH treatment failed to stimulate vitellogenesis in fish in the early stages of the reproductive cycle; however, gonad stimulation and increases in plasma hormone values were observed after females were treated with an extract of whole pituitaries taken from vitellogenic Pacific salmon.

\section{Introduction.}

Seasonal gonad recrudescence requires the integrated activities of the pituitary gland, the liver, and the gonads. In common with other lower vertebrates, a vitellogenic protein is produced in the liver of the female teleost under estrogen stimulation. This material is transported via the blood to the gonad, under pituitary mediation (Campbell and Idler, 1976).

The triggers for and regulation of the vitellogenic processes are poorly understood. The present study was designed to collect data for profiles of gonadotropin $(\mathrm{GtH})$, estradiol $\left(\mathrm{E}_{2}\right)$, and vitellogenin $\left(\mathrm{V}_{\mathrm{g}}\right)$ levels related to the reproductive cycles of the female brown trout, Salmo trutfa. The effect of LH-RH and pituitary extract on these plasma indicators of sexual development was examined.

\section{Materials and methods.}

Experimental animals. - Wild adult brown trout, Salmo trutta, were collected from a local pond using fyke nets. The fish were transported to the laboratory and held without feeding in aquaria provided with a single pass freshwater supply and simulated natural photoperiod. 
Experimental design. - All fish were bled 1 day following capture, and again 7 and 14 days after the beginning of hormone treatment. Blood samples from the caudal vasculature were drawn into heparinized syringes and the resulting plasmas were divided into aliquots and stored frozen until hormone assays were performed.

Hormone preparations. - Synthetic LH-RH (amide form) was dissolved in $0.05 \mathrm{M}$ tris, $\mathrm{pH} 7.7$ containing $3.75 \mathrm{p} .100 \mathrm{w} / \mathrm{v}$ gelatin. Fish treated with LH-RH received $100 \mu \mathrm{g}$ i.p. in $0.3 \mathrm{ml} / 454 \mathrm{~g}$ body weight. Pituitaries from vitellogenic sockeye salmon were homogenized in tris buffer. The salmon gonadotropin hormone potency of this extract $(84.8 \mu \mathrm{g} / \mathrm{ml}$-salmon $\mathrm{GtH}$ radio-immunoassay) was $74.1 \mathrm{SG} *$ units $/ \mathrm{ml}$. Fish treated with crude pituitary extract received 2 pit. equivalents i.p. in $0.3 \mathrm{ml} / 454 \mathrm{~g}$ body wt. Control fish received $0.3 \mathrm{ml}$ vehicle solution only. All groups of fish received treatment twice each week, a total of 4 injections.

Hormone assays. - Radioimmunoassay techniques (RIA) were used to measure plasma concentrations of gonadotropin $(G+H)$, estradiol $\left(E_{2}\right)$, and vitellogenin $\left(V_{g}\right)$. The method for measuring salmonid $\mathrm{GtH}$ was previously reported (Crim, Watts and Evans, 1975). A similar method has been developed for $V_{g}$ RIA (Idler, Hwang and Crim, unpublished). Briefly, a rabbit antibody was produced against twice precipitated Atlantic salmon yolk lipophosphoprotein. A highly purified yolk lipophosphoprotein preparation was iodinated by the Chloramine $T$ method (Greenwood, Hunter and Glover, 1963). The antibody to the purified yolk lipophosphoprotein was shown to cross react with the major plasma lipophosphoprotein. The $E_{2}$ RIA was developed according to the instructions obtained with the $E_{2}$ antiserum from Dr. G. Abraham. The protocol was modified for $E_{2}$ purification from plasma samples by using Sephadex LH-20 (DeJong, Hey and Van Der Molen, 1973).

Gonad analysis. - Sections of ovaries were examined histologically to evaluate oocyte development by the classification of Ishida, Takagi and Arita (1961). Small pieces of ovary were removed for the analysis of yolk lipophosphoprotein (Pv) by $V_{g}$ RIA. Tissues were homogenized in $0.5 \mathrm{M} \mathrm{NaCl}, 5 \mathrm{mM}$ EDTA and held at $4{ }^{\circ} \mathrm{C}$ for $30 \mathrm{~min}$. After centrifugation for $60 \mathrm{~min}$. at $24000 \mathrm{~g}$ the supernatant fluid was removed for RIA.

Statistical analysis. - The student « $\dagger »$ test was used to compare groups.

\section{Results.}

Seasonal reproductive development of the female brown trout under natural conditions begins in the summer in preparation for the fall spawning period. Female trout were collected at the beginning, during, and at the completion of gonadal growth and development. Significant changes in gonadosomatic index (GSI) were not apparent until August (table 1); GSI rapidly increased thereafter and peaked in October. Histological evidence suggested that vitellogenesis was underway in June since all oocytes had progressed to the primary yolk stage. Increased yolk Pv accumulation

* $1 \mathrm{SG}$ unit $=1 \mu \mathrm{g}$ NIH-LH-S18 in the chick bioassay. 
in June compared to May $(P<0.005)$ supported this conclusion. Ovary Pr concentration increased in August but declined at the October sampling ; with ovary weights growing larger, total ovary Pv continued to increase as full maturity approached in October.

\section{Table 1}

Changes in gonadosomatic index (GSI), ovary phosvitin (Pv) concentrations and fotal Pv accumulation, and oocyfe stage of development of female brown trout associated with the seasonal reproductive cycle

\begin{tabular}{|c|c|c|c|c|c|c|c|c|}
\hline \multirow{2}{*}{$\begin{array}{l}\text { Date of } \\
\text { sacrifice }\end{array}$} & \multirow{2}{*}{$N$} & \multirow{2}{*}{ GSI (p. 100) } & \multirow{2}{*}{$\begin{array}{c}\text { PV } \\
\text { concentration } \\
(\mu \mathrm{g} / \mathrm{mg})\end{array}$} & \multirow{2}{*}{$\begin{array}{c}\text { PV } \\
\text { total } \\
(\mu g / g \text { body wt. })\end{array}$} & \multicolumn{4}{|c|}{$\begin{array}{c}\text { Stage of oocyte }(b) \\
\text { development }\end{array}$} \\
\hline & & & & & OG & PY & SY & oV \\
\hline $\begin{array}{l}\text { May } 10 \ldots \\
\text { June } 10 \ldots \\
\text { August } 26 . \\
\text { October } 21\end{array}$ & $\begin{array}{r}7 \\
12 \\
5 \\
5\end{array}$ & $\begin{array}{l}0.57 \pm 0.09{ }^{(a)} \\
0.67 \pm 0.05 \\
4.63 \pm 0.85 \\
18.82 \pm 4.58\end{array}$ & $\begin{array}{l}0.29 \pm 0.17\left({ }^{a}\right) \\
1.31 \pm 0.21 \\
4.92 \pm 0.45 \\
1.78 \pm 0.19\end{array}$ & $\begin{array}{c}2.26 \pm 1.56\left(^{a}\right) \\
8.85 \pm 1.42 \\
236.01+61.86 \\
334.29 \pm 52.03\end{array}$ & $\frac{3}{-}$ & $\begin{array}{r}4 \\
12 \\
4 \\
-\end{array}$ & $\overline{-}$ & $\frac{-}{2}$ \\
\hline
\end{tabular}

$(a)=$ Mean \pm SE.

$(b)=$ stages of vitellogenesis (Ishida, Takagi and Arita, 1961); OG $=$ oil globule, $P Y=$ primary yolk, $S Y=$ secondary yolk, OV = ovulated but not spawned.

Plasma profiles for $\mathrm{GtH}, \mathrm{E}_{2}$, and $\mathrm{V}_{\mathrm{g}}$ levels associated with the female trout reproductive cycle are presented in figure $1 a$. Plasma $\mathrm{GtH}$ was very low throughout the cycle. Although these fish normally spawn in November, significant GtH increases were observed in fish nearing oocyte maturation in October ; $E_{2}$ and $V_{g}$ both significantly increased in August with further increases observed in the October sample.

Manipulation of the female trout reproductive cycle was attempted with vitellogenic fish in June using either LH-RH or an extract of whole sockeye salmon pituitary glands. Intraperitoneal treatment with LH-RH over a 2 week period failed to produce changes in plasma $\mathrm{GtH}, \mathrm{E}_{2}$ or $\mathrm{V}_{\mathrm{g}}$ values (fig. $1 b$ ). Likewise, GSI and ovary Pr values were not significantly altered (data not shown). Treatment of female brown trout with a crude extract of maturing salmon pituitary glands, however, significantly increased $(P<0.02)$ both GSI $(0.95 \pm 0.27$ from $0.67 \pm 0.16)$ and total ovary Pv $(20.76 \pm 5.38$ from. $8.85 \pm 1.42)$ and significant elevations in plasma $E_{2}(P<0.01)$ and $G+H(P<$ $0.005)$ were sustained for the 2 week treatment period. Plasma $V_{g}$ levels were not significantly altered.

\section{Discussion.}

The levels of $E_{2}$ and $V_{g}$ in the plasma progressively rise over the course of the female seasonal reproductive cycle and parallel increases occur in yolk Pv levels in the gonad as development continues. Gonadotropin levels are low and steady during much of the gonad development period. Very modest GtH changes were previously reported (Crim, Watts and Evans, 1975) for trout and salmon during the early vitellogenic period and also for the time of accelerated ovarian development. Late in the reproductive cycle dramatic increases in $\mathrm{GtH}$ are usually found in spawning fish. 

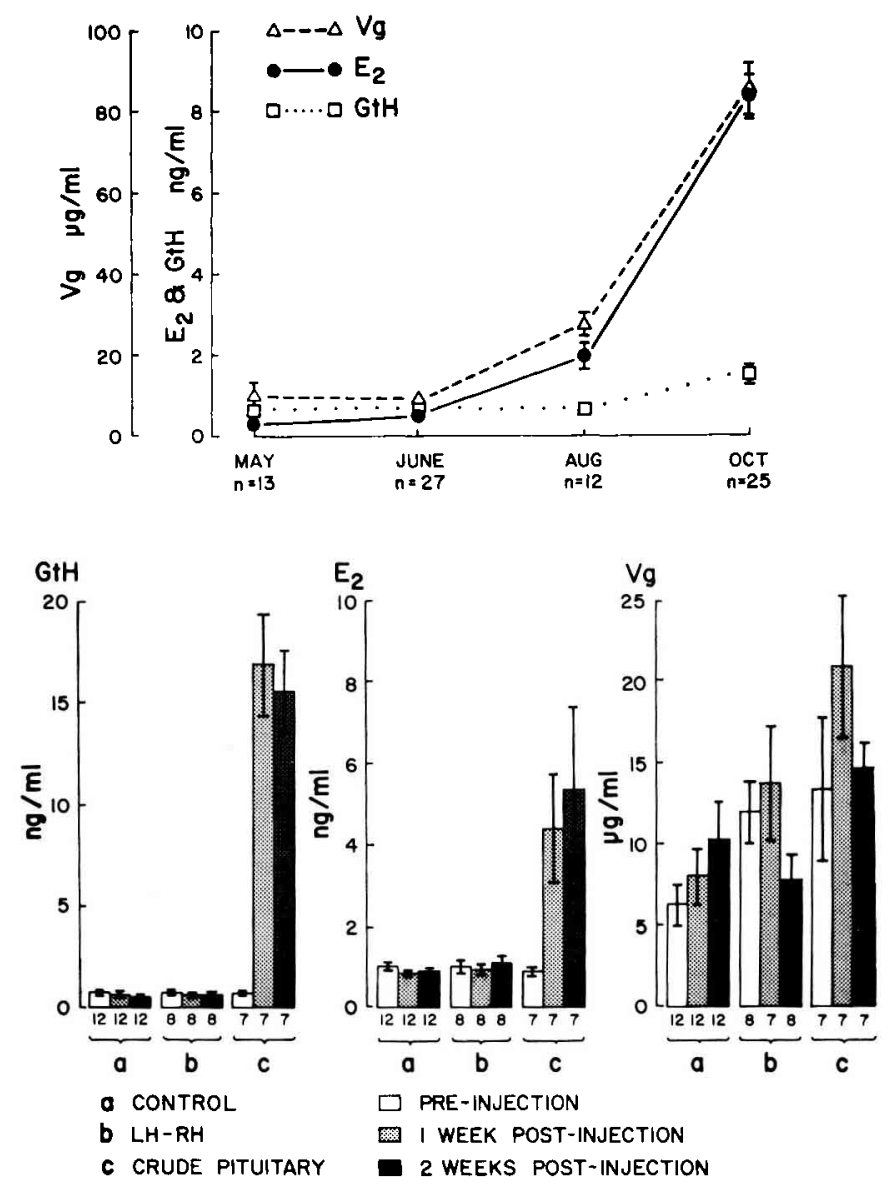

FIG. 1a. - Profiles of plasma $G H, E_{2}$, and $V_{g}$ associated with the seasonal reproductive cycle of female brown trout. Symbols represent means and vertical lines \pm SEM. When SEM is not shown it is too small for the scale.

FIG. 1b. - Plasma GHH, $E_{2}$, and $V_{\mathrm{g}}$ values in female brown trout before and after treatment with $L H-R H$ or a crude extract of salmon pituitary gland. Bars and lines represent means \pm SEM. The $n$ values appear beneath the bars.

Rainbow trout show increasing plasma $\mathrm{GtH}$ and $\mathrm{E}_{2}$ levels during the late stages of vitellogenesis, but while $\mathrm{GtH}$ continues to increase during germinal vesicle breakdown, $E_{2}$ values are reported to decline (Breton et al., 1975).

Although synthetic LH-RH stimulates $\mathrm{GHH}$ release in the sexually mature carp and trout (Weil, Breton, and Reinaud, 1975 ; Crim and Cluett, 1974), LH-RH in the present study failed to increase plasma $\mathrm{GtH}, \mathrm{E}_{2}$, and $\mathrm{V}_{\mathrm{g}}$ levels of the trout during the early phases of vitellogenesis. Therefore, the mechanism for neural regulation vitellogenic process remains to be defermined. Species differences may exist with respect to the $\mathrm{LH}-\mathrm{RH}$ sensitivity of fish at various stages of the reproductive cycle 
because Chan (1977) showed that LH-RH promotes ovary growth and maturation in the regressed Japanese Medaka.

The results of the present experiment indicate that the salmon pituitary gland contains a vitellogenic factor(s), possibly gonadotropin, capable of increasing plasma estradiol levels and enhancing gonad accumulation of phosvitin. Other pituitary substances in addition to classical glycoprotein gonadotropin, have been shown to stimulate vitellogenesis (Campbell and Idler, 1976) and the nature of the vitellogenic material in the salmon pifuitary remains to be elucidated.

Symposium sur la Reproduction des Poissons Paimpont, France, 19-21 septembre 1977.

Acknowledgments. - The authors whish to thank Mrs. L. Taylor and Mr S. Hwang for technical assistance. This work was supported by grant A9729 to L. W. Crim and A6732 to D. R. Idler. The donation of synthetic LH-RH by The National Institutes of Health is gratefully acknowledged. MSRL Contribution number 286.

Résumé. L'évolution de la gonadotropine, de l'estradiol ef de la vitellogénine dans le plasma de truites Fario femelles a été suivie pendant le cycle saisonnier de reproduction. L'accumulation de lipophosphoprotéines (phosvitine) dans le vitellus a été également suivie. L'estradiol et la vitellogénine plasmatique augmentent progressivement, en même temps que la phosvitine dans le vitellus. Pendant le développement de l'ovaire, le niveau plasmatique de la gonadotropine reste bas jusqu'à la phase de maturation finale des ovocytes. Un traitement au LH-RH ne stimule pas la vitellogenèse durant les premiers stades du cycle de reproduction, cependant on observe une stimulation de l'ovaire et une élévation du niveau de la gonadotropine dans le plasma quand les femelles sont traitées par un extrait hypophysaire préparé à partir d'hypophyses de saumon prélevées en période de vitellogenèse.

\section{References}

BRETON B., JALABERT B., FOSTIER A., BILLARD R., 1975. Etude sur le cycle reproducteur de la truite arc-en-ciel et de la tanche. Effect de variations expérimentales de la température. J. Physiol. Paris., 70, 561-564.

CAMPBELL C. M., IDLER D. R., 1976. Hormonal control of vitellogenesis in hypophysectomized winter flounder (Pseudopleuronectes americanus Walbaum). Gen. comp. Endocr., 28, 143-150.

CHAN K. K. S., 1977. Effect of synthetic luteinizing hormone-releasing hormone (LH-RH) on ovarian development in Japanese medaka, Oryzios latipes. Can. J. Zool., 55, 155-160.

CRIM L. W., CLUETT D. M., 1974. Elevation of plasma gonadotropin concentration in response to mammalian gonadotropin releasing hormone treatment of the male brown trout as determined by radioimmunoassay. Endocrinol. Res. Comm., 1, 101-110.

CRIM L. W., WATTS E. G., EVANS D. L., 1975. The plasma gonadotropin profile during sexual maturation in a variety of salmonid fishes. Gen. comp. Endocr., 27, 62-70.

DeJONG F. H., HEY A. H., VAN DER MOLEN H. J., 1973. Effect of gonadotropins on the secretion of œstradiol-17 $\beta$ and testosterone by the rat testes. J. Endocr., 57, 277-284.

GREENWOOD F. C., HUNTER W. M., GLOVER J. S., 1963. The preparation of 131/-labelled human growth hormone of high specific radioactivity. Biochem. J., 89, 114-123.

ISHIDA R., TAKAGI K., ARITA S., 1961. Criteria for the differentiation of mature and immature forms of chum and sockeye salmon in northern seas. Bull. int. North Pac. Fish. Comm., 5, 27-47.

WEIL C., BRETON B., REINAUD P., 1975. Etude de la réponse hypophysaire à l'administration de Gn-RH exogène au cours du cycle reproducteur annuel chez la carpe Cyprinus carpio. $C$. $R$. Acad. Sci., série D, 280, 2469-2472. 